\title{
Michel Foucault e a comunicação como acontecimento
}

Ciro Marcondes Filho (USP) ${ }^{1}$

\section{Resumo}

No início, preocupado com a descontinuidade anônima do saber, Foucault vai atrás das teorias da representação; posteriormente, constatando a falência do discurso humanista, realiza, com o apoio de Freud, Marx e Nietzsche, sua "escavação das alturas" a fim de trabalhar o perverso embutido da linguagem e praticar o "pensamento a partir do exterior". Sua proposta de pesquisar as estruturas subjacentes do saber convive em harmonia com a teoria dos incorpóreos que Foucault parece utilizar. Entretanto, nem tudo está bem explicado: seu enaltecimento da lingüística no século 20 , com suas incríveis capacidades para matematizar e formalizar o pensamento, que a aproximam inequivocamente da totalidade do estruturalismo, não combinam com a pesquisa do acontecimento, de filiação estóica. Mais ainda: o sujeito, que ele pretendeu extirpar, continua a sobreviver na forma pulverizada; a liberdade, de herança sartreana, que ele apregoa, também é repressora e a noção de poder, central em suas obras, não parece ter sido totalmente desacoplada de uma visão metafísica.

Palavras-chaves: Inconsciente do saber; hermenêutica da comunicação; teoria dos incorpóreos; teoria do acontecimento; poder.

\section{Abstract}

In his beginning, devoted to the investigation of the anonymous discontinuity of knowledge, Michel Foucault goes after the representation's theories. Afterwards, when he takes account of the failure of Humanistic discourse he undertakes - relying on Freud, Marx and Nietzsche - his "excavations of the heights" aiming to work in the perverse at the inner of language and to practice a way of thinking setting out "from the exterior". His proposals to study the subjacent structures of knowledge lives in harmony together with the theory of the incorporeals, that Foucault seems to use. However, not everything seems to be explained: his exaltation of Linguistics in $20^{\text {th }}$ century, with its incredible capacities to mathematize und to formalize the thought, that brings it near to 
Structuralism do not combine with his stoic research of the Event. Moreover: the subject that he intended to exclude goes on living in its pulverized form; the freedom that he proclaims - his Sartrean heritage - is repressive as well and the notion of power - central in his writings - does not seem to be separated from a metaphysical way of looking.

Keywords: The unconscious of knowledge; communication hermeneutics; theory of the incorporeals; theory of events; power

\section{O fim da liberdade do homem e a emergência do discurso ${ }^{2}$}

Ao descrever em $A$ ordem do discurso o que significa um autor, Michel Foucault nos dá um espelho de si mesmo: "um homem que pôde revolucionar a imagem tradicional que se tem de um autor, talhando, a todo instante, um perfil ainda tremulante de sua obra". Um autor que sempre mudou: mudou de tema, mudou de estilo, mudou de orientação metodológica, mudou de objetos. Há numa primeira parte em suas obras, constituída das pesquisas sobre a loucura e a clínica, que chegam até Arqueologia do saber. Daí em diante, após seu ingresso no Collège de France, Foucault parece liberar-se das amarras anteriores, saindo, especialmente em História da sexualidade, em busca de outras pesquisas, de uma outra intervenção intelectual e teórica.

Foucault faz parte da geração que se formou na França a partir da fenomenologia de Husserl, introduzida por Emmanuel Lévinas. Foi husserliano, sartreano e sofreu, como todos intelectuais dessa época, forte influência de Merleau-Ponty. Mas o existencialismo de Sartre desabou, surgindo daí um grande vácuo na metade dos anos 50 que fez proliferar o modelo estruturalista que havia começado com Saussure, no início do século 20, e tinha ganho, com Lévi-Strauss, um salto qualitativo surpreendente. Foucault negou sistematicamente sua inclusão nesse movimento, apesar de ter declarado dele participar em 1966. Seu interesse principal foi a pesquisa da descontinuidade anônima do saber.

A primeira obra que ganhou grande destaque foi As palavras e as coisas, de 1966. Nesta pesquisa, Foucault compara a operação do signo lingüístico no século $17 \mathrm{com}$ a do século 19. No primeiro caso, período da 
episteme clássica, a teoria da representação constitui o fundamento de diversas ordens do saber, como a lingüística, a biológica, a econômica, a política. Busca-se a constituição de uma ciência geral da ordem, organizada como matesis universal para as estruturas simples, associada à quantidade, e como taxonomia para estruturas complexas, associada à qualidade.

A representação clássica é o eixo teórico da gramática geral (de PortRoyal), da história natural e da análise das riquezas. No caso que nos interessa particularmente, o da linguagem, competia ao sistema de signos exprimir todas as representações e à língua, efetivamente traduzir o que cada coisa é. Desta forma, contudo, operando com um austero paradigma da representação, a gramática de Port-Royal promovia um efetivo enrijecimento da teoria da significação, excluindo do processo de sentido qualquer referência à conjuntura. No período helenístico, os estóicos haviam superado a fórmula aristotélica de sujeito, predicado e sua cópula, adicionando à sua semiologia um terceiro termo: a idéia ou sensação obtida ao se ouvir uma palavra - que se adicionava ao termo usado (o significante) e à própria coisa (o referente). $\mathrm{Na}$ regressão provocada pela episteme clássica, a lógica de Port Royal substitui novamente o sistema ternário pelo binário, o significante volta a remeter diretamente a apenas um significado e a parte viva do signo desaparece. A substituição do sistema ternário acaba por inviabilizar o incorpóreo, este sentido que vai muito além da noção de significado, uma idéia que só se constitui no momento da fala e que não tem tradução no plano formal da linguagem.

Além disso, a gramática de Port-Royal oficializa a vinculação da linguagem a traços metafísicos (fato esse mais tarde criticado, inclusive, na lingüística estrutural de Saussure). A divinatio, diz Foucault, supunha sempre sinais que eram anteriores à dotação de sentido, uma significação mais ou menos oculta, cuja tarefa era descobrir uma linguagem prévia, distribuída ao mundo por Deus.

A era moderna já não trabalha com a representação. O saber agora vai buscar sua confirmação na nova objetividade fornecida pela história, que faz com que a ciência das riquezas transforme-se em economia política, a história natural torne-se biologia e a gramática geral, filologia. Já não se trata mais de saber se a coisa é ou não corretamente representada pelo saber mas quem 
está falando e sobre o que se está falando. Quer dizer, quem assume a posição principal é o homem, ele é tanto objeto das novas ciências como o sujeito do saber moderno. Mas Foucault não pára aí: esse homem, que emerge como valor na era moderna, é uma criação recente e está ameaçado de desaparecimento próximo (não o homem fisicamente, como é óbvio, mas o homem como "certa figura do saber").

Assim, antes havia o discurso (da representação), depois veio o homem (figura do saber), agora, é hora novamente do retorno do discurso, diz Foucault. Homem e discurso não podem conviver pacificamente. $O$ discurso que retorna é o da virada lingüística, Foucault não o exprime literalmente, mas é evidente que se trata disso. É a linguagem que surge na passagem para o século 20 "com insistência cada vez maior", é o ser da linguagem que agora "brilha no horizonte" (Foucault, 1966a, p. 500). O homem, diz Foucault, vai desaparecer não tanto como objeto do saber, afinal, o pensamento e a filosofia continuam sua investigação sobre ele, mas como sujeito da liberdade e da existência. Neste último ponto, Foucault, exclui, de uma tacada, a fenomenologia de Heidegger e o existencialismo de Sartre.

A teoria do discurso de Foucault é eminentemente estruturalista. Foucault diz que as regras de formação da língua não se enraízam na mentalidade ou na consciência dos indivíduos mas no próprio discurso que se impõe a todos os indivíduos que atuam no campo discursivo como uma espécie de anonimato uniforme. Desde o início do século 19, os estudos lingüísticos procuraram as "grandes constantes" do espírito humano; ao estudarem as palavras, a evolução das gramáticas, ao fazerem comparações entre as línguas, esperava-se a revelação do homem, "a unidade de seu rosto", seus "diferentes perfis", contudo, o que se encontrou de fato, diz ele, foram apenas estruturas.

Não há como negar essa paixão pelas estruturas: a atuação do discurso não como um sistema produzido por alguns homens e significando coisas mas como algo que se autoproduz e dotado de auto-referência. Que não tem nada a ver com sujeitos que pensam, elaboram e se manifestam. No universo da linguagem, os homens se dispersam e se tornam descontínuos, não podendo haver, portanto, nenhuma liberdade humana, visto que o homem não é livre, sua liberdade não passa de algo outorgado pelo próprio discurso. 


\section{A linguagem e a relação de amor-ódio com o estruturalismo ${ }^{3}$}

Seguindo os passos anteriores, Foucault sai, em Arqueologia do saber e em $A$ ordem do discurso, em busca das práticas discursivas "quase puras" (Blanchot), aquelas práticas só remetem a si mesmas. Sua arqueologia sugere uma escavação dos determinantes submersos do saber, daquilo que seria esta descontinuidade anônima do conhecimento. Contudo, ele já não pretende ser visto como um estruturalista, pois suspeita que sob a noção de estruturas escondam-se formas transcendentais instaladas nas leis formais que regem a ciência e que são estranhas à historicidade. Ao que parece, diferente dos estruturalistas clássicos, Foucault ainda acredita num certo tipo de historicidade. Trata-se de escavar, de buscar os condicionantes subterrâneos do discurso, um escavação, contudo, singular, pois se trata de escavar as alturas, como estaria supostamente operando o filósofo Nietzsche em seu Zaratustra.

Vejamos como isso funciona. Foucault desconfia da linguagem. Por um lado, ela não diz exatamente o que ela diz; há um sentido externo, menor, enganoso, competindo com um outro, mais poderoso, que corre "por baixo". Mas não nos apressemos em caracterizar tal procedimento como um platonismo elementar, pois há outras implicações mais sérias. Em princípio, Foucault não considera que a linguagem seja tudo, pois "há outras coisas no mundo que falam e que não são linguagem" (Foucault, 1967, p. 565), assim como há uma linguagem em outro lugar que não na linguagem (idem). Quando fala isso, ele está pensando nos grandes autores que desmascararam os discursos: Nietzsche, Freud, Marx.

$\mathrm{Na}$ era clássica, quando a linguagem representava, o signo poderia ser visto como algo "benigno", pois as coisas se pareciam com seus representantes lingüísticos, mas na modernidade deparamo-nos com outro olhar, menos ingênuo, que encara o signo como fundamentalmente perverso. Nietzsche, Freud e Marx viram nele formas ambíguas, equívocas, marcadas por uma malignidade de origem. Agindo assim, eles revolucionaram a teoria da interpretação, dando um novo sentido às coisas que não tinham sentido, 
mudando a natureza do signo. No limite, segundo eles, a interpretação é impossível e remete à loucura.

Foucault trabalha com Nietzsche porque este pode afastar o fantasma das estruturas transcendentais, ao combater duramente a metafísica; Marx, por seu turno, impede que a historicidade recaia sobre os homens, de vez que acredita que a história, mesmo sendo feita pelos homens, estes a fazem inconscientemente e sob condições históricas dadas; e é por aí também que Foucault apela para Freud, pois foi ele quem descobriu nossa sujeição à figura do inconsciente. Em suma, esses três autores banem por completo, cada um à sua maneira, as ilusões humanistas e sugerem um outro modo de pensar que aparentemente se desvia dos vícios do estruturalismo, pelo menos, da forma como o conhecemos em Saussure e em Lévi-Strauss, que, ao que parecem, ainda guardam resquícios metafísicos.

Conhecemos a refutação do estruturalismo também e Deleuze e em Derrida. Deleuze e Guattari, no Anti-Édipo, rompem com o modelo freudiano do teatro do Édipo e propõem o inconsciente funcionando "como fábrica"; nesta mesma obra e em Mil Platôs, refutam a aporia lacaniana, especialmente em seu conceito de desejo, que ele substituem pelo de máquina desejante. 0 inconsciente para eles não se estrutura como linguagem (o mesmo havia dito Jean-François Lyotard em Discurso, figura). Derrida, por seu turno, refuta também Saussure e Lacan. Mas em Foucault, diferente de Deleuze e de Derrida, há a sobrevivência do pensamento de Marx e de "uma certa historicidade", como mencionamos acima.

Marx, Freud e Nietzsche são autores que sugerem um pensamento a partir do exterior, um pensamento que venha de fora, um pensamento que trabalhe com os signos a partir de uma perspectiva distanciada. A subjetividade criativa, que conhecemos de Husserl, não interessa a Foucault. Mesmo a experiência interior de um Bataille não é considerada em suas argumentações. Nada disso; é preciso sair de toda subjetividade, indicando, ao mesmo tempo, o limite exterior desta. O pensamento a partir do exterior enuncia o fim dessa subjetividade, aponta sua dispersão, fala que nela reside uma ausência insuperável; ao mesmo tempo, ele é indicação da positividade do pensamento, pensamento esse que não se ancora na subjetividade mas que busca ver onde 
ela está instalada, como é o vazio de seu lugar, como se constitui sua distância e como se esquivam suas certezas.

De fora mas também das alturas. A exterioridade, diz Foucault, foi encoberta, soterrada. Há de haver, portanto, um escavador, um personagem que realize uma escavação insólita, pois, trata-se de notar não o que está de fato nas profundezas, mas aquilo que sai do prumo, que realça, que destoa. Uma profundidade enganosa, que se dizia profunda mas que é superficial, que salta à vista. Escavar o que desponta na montanha e denunciar seu caráter impostor.

É a isso que Foucault se refere quando fala em encontrar um saber inconsciente na história da ciência, dos conhecimentos, do saber humano. É a história da ciência, a história dos progressos humanos que não obedece à razão humana, que não é a consciência humana detendo as leis de sua história; há, abaixo desta história, algo desconhecido.

De certa forma, a continuidade dos pensamentos de Nietzsche, Freud e Marx, as esperanças de desvelar esse continente submerso, caberia, no século 20, ao pensamento estrutural e à lingüística. A lingüística vai herdar essa incumbência num contexto já não-humanista, avesso à metafísica e sintonizado com uma certa cientificidade de início de século 20, antes positivista, marcada por Wittgenstein e pelo Círculo de Viena, pelo pragmatismo e pela teoria da informação. Foucault encanta-se, como tantos outros, com as perspectivas que os estudos lingüísticos abrem à sociedade. A lingüística, no século 20 , alçava um prestígio além das demais ciências humanas e poderia se situar no mesmo patamar das ciências tradicionalmente constituídas, as ciências duras. Sua afinidade com todos os fenômenos da informação lhe permitiria - enaltecia vigorosamente Foucault - formalizar e matematizar altamente as análises lingüísticas. "De um golpe, a lingüística encontrava-se entrando em convivência com as análises que se referem aos códigos e às mensagens trocadas entre moléculas que constituem nós de células vivas" (Foucault, 1969c, p. 826). A partir de Saussure, já podemos tratar com pólo emissor, de um lado, e pólo receptor, de outro. Podemos operar com mensagens, quer dizer, séries de acontecimentos distintos, podemos trabalhar com códigos e regras de construção dessas mensagens. 
Era evidente que Foucault incorporava a mesma ilusão cientificista que certa vez contagiou tanto Freud e Marx, como o neocientificismo do início do século passado. O valor do discurso, o discurso do saber, mede-se pela credibilidade oficial e instituída dos saberes - mesmo convencionais - já instalados. Em momento algum se poderia exigir para as ciências humanas um estatuto próprio de validade e de prestígio, absolutamente distinto dos critérios de validade das ciências clássicas. Ao contrário, as ciências humanas, bem no espírito do Círculo de Viena, deveriam desbastar tudo o que ainda portavam de intuições, especulações, suposições baseadas em insights e em sensações.

E, de fato. O Círculo de Viena, como sabemos, desdobrou-se no Círculo Cibernético, que floresceu nos Estados Unidos e que cegou outros teóricos europeus, como Edgar Morin. E Michel Foucault fascinava-se com as perspectivas tecnocráticas da ciência da linguagem. Dizia, na mesma citação, que agora o social poderia ser definido ou descrito como um conjunto de códigos e de informações que caracterizam um grupo dado de emissores e de receptores. O saber humanista, assim, capitulava diante da nova moda da ciência da informação.

Ora, todo esse entusiasmo tecnocrático não combinava com as estruturas subjacentes do saber, pois estas, diferentes do fascinante alvorecer lingüístico, não são transformáveis em códigos, não remetem ao esquema simplista de emissores e receptores, evocam, ao contrário, continentes inteiros submersos. É preciso, portanto, repensar a ordem do discurso. Na apresentação de posse de uma cadeira no Collège de France, em 1970, temos um Michel Foucault que se diz romper com o estruturalismo e que agora fala no acaso, no descontínuo, no acontecimento. Foucault está maduro para sintonizar com a proposta da comunicação.

\section{A teoria da comunicação e as insuficiências de Foucault ${ }^{4}$}

O olhar de Michel Foucault à comunicação remete à nossa teoria do acontecimento. Uma enunciação inicialmente lingüística articula-se com acontecimentos outros, não diretamente discursivos, como são os fatos técnicos, econômicos, sociais, políticos, práticos, etc., constituindo juntos um processo comunicacional. A pesquisa foucaultiana, buscaria, assim, estudar o 
aparecimento desses enunciados, sua manutenção, os laços que estabelecem entre si, a forma pela qual podem ser reunidos em um conjunto, o papel que eles exercem, os valores que os afetam, a forma como são investidos em condutas, o princípio segundo os quais circulam.

Margarida Gouvêa defende a tese de que Foucault segue a teoria estóica dos incorpóreos. Segundo essa teoria, seres reais entram em relação com outros seres reais e podem, por meio desta relação, se modificar. Uns não são causas dos outros, mas, uns pelos outros, são causas de certas coisas. Um corpo não pode modificar outro corpo, o que há é uma mistura, mistura de corpos que se interpenetram em sua intimidade. Tudo muito próximo ao conceito de comunicação de Emmanuel Lévinas, Martin Buber e Georges Bataille. Também ao conceito de comunicação de Maurice MerleauPonty, em relação ao diálogo. Acontecimentos produzem efeitos, como, por exemplo, a marca: o fogo esquenta o ferro, não Ihe altera a qualidade, mas pode marcá-lo.

Gouvêa vê os mesmos mecanismos em Foucault: também para ele, o corpo é lugar de origem. Sobre ele encontra-se o estigma de acontecimentos passados e é nele que nascem desejos, erros, desfalecimentos. "Nele, também, os acontecimentos se atam e se exprimem, mas nele também se desatam, entram em luta, se apagam uns aos outros e continuam seu insuperável conflito" (Gouvêa, 1989, p. 8). Os signos, em Foucault, são vazios e seu sentido é preenchido pelos acontecimentos.

Naturalmente, a opção pelo acontecimento bate de frente com o modelo estruturalista de pensar, já que, para este método, o todo, mesmo pensado como virtualidade, é sempre maior que as partes e cabe ao acontecimento ser apenas a parte, mero significante, cuja real significação só pode ser deduzida do todo. No pensamento estóico isso não se passa, pois, para ele a qualidade nasce do estado, do modo próprio do acontecimento, sem qualquer intervenção de uma força exterior. Fatos, para os estóicos, são únicos. "Vê-se, então, que o pensamento que busca observá-los e descobrir suas ligações fica de fora, torna-se estranho a eles" (idem, p. 28).

Por aí se vê que Foucault rompeu de fato com o estruturalismo nesta altura de sua produção teórica, ao propor, por exemplo, à história, não mais a compreensão do acontecimento pelo jogo de causas e efeitos, para encontrar 
estruturas que, em última análise, são estranhas ao próprio acontecimento; não, agora Foucault fala em séries diversas, entrecruzadas, amiúde divergentes mas não autônomas, que circunscrevem o lugar de sua ocorrência, seu acaso, as condições de seu aparecimento.

Neste ponto, o método de Foucault cruza-se com o da Nova Teoria da Comunicação, que propõe, da mesma maneira, regularidades, acasos, descontinuidades, transformações. Quando Foucault insiste na categoria do acaso, também aqui está próximo de Serres, que fala dos fluxos e sua característica de permitir o fugaz, o fugidio, aquilo que é vivo nos sistemas, que é instável e estável ao mesmo tempo. Foucault pretende introduzir o acaso como categoria na produção de acontecimentos.

De forma estóica, Foucault fala que o acontecimento não é substância nem acidente, qualidade ou processo; ele não é da ordem dos corpos, mas, tampouco é imaterial (o que é então, senão o próprio incorpóreo?). Ele opera na relação, na coexistência, na dispersão, no recorte: "não é ato nem propriedade dos corpos, ele se produz como efeito da e na dispersão material" (Foucault, 1970, p. 59), repetindo aqui, sem mencionar, a cartilha dos estóicos. E, com efeito, na página seguinte é ele mesmo quem reconhece que a filosofia do acontecimento deveria avançar na direção paradoxal à primeira vista de um materialismo do incorpóreo.

Michel Foucault é um autor que desconcerta, pois navega por vários paradigmas teóricos, por várias epistemas, sem estar à vontade com nenhum deles. Mauriche Blanchot diz que ele cai numa teologia negativa, conceito que já conhecemos em Theodor Adorno e na Escola de Frankurt, ao isolar uma forma mesmo quando busca livrar-se da interpretação, da originalidade e da soberania do significante. Essa forma seria o enunciado. Pierre Bollouet também acha que ele tem um pouco do freudo-marxismo mas, antes disso, ele teria oscilado entre uma fenomenologia e um estruturalismo. $O$ lado freudomarxista de Foucault seria recente, estaria em sua maturidade (em 1975) ao insistir na revolta dos corpos indóceis submetidos à sociedade carcerária.

Maurice Blanchot acha, também, que Foucault não se desembaraça corretamente da noção de sujeito. Dizer que não há mais obras, autor, unidade criadora é uma coisa, mas não é bem essa a questão. O sujeito não desaparece mas pulveriza-se: a unidade do sujeito dissolve-se em uma 
pluralidade de posições e de funções descontínuas. Esse é o mistério do contexto atual que Foucault parece não perceber, pois atém-se a materialidades.

Em relação à herança sartreana, Foucault não parece ter se desvencilhado totalmente da ilusão da liberdade. Ela reaparece no fim de sua carreira, quando, abandonando modelo seguido entre 1961 e 1976, que atribuía à episteme, aos poderes, aos dispositivos a produção das posições de médico e paciente, psiquiatra e louco, opta, em 1984, por uma referência antes à consciência ética do que a uma posição de poder instituído. Ora, para quem conhece as malhas do poder e seus mecanismos subreptícios, a suposição de uma liberdade, mesmo que opere na sexualidade, soa ingênua. A liberdade também reprime, diz Jean Baudrillard, criticando a declaração de Foucault, de que "nada funciona pela repressão, tudo funciona pela produção - nada funciona pelo recalcamento, tudo funciona pela liberação". Ora, diz Baudillard, é a mesma coisa!

Por fim, como já sugerimos no item anterior, Foucault parece ser um autor seduzido pelo pensamento técnico. Seu conceito de espaço assemelhase de forma suspeita aos espaços físicos e matemáticos, presentes também em Gilles Deleuze. Trata-se de um "conluio" que Jean Baudrillard pretende denunciar, ao ver nos rizomas estruturas que se assemelham ao Castelo de Kafka, esquemas de desejo que se misturando a esquemas de controle.

Da mesma forma como não capta o indivíduo, Foucault parece não captar tampouco devidamente o poder. Baudrillard acha que Foucault não percebe que o poder parece se extinguir, pois usa-se de estratégias de reversão, de desaparecimento, mas que é essa exatamente sua forma, a de nunca estar ali, de sua presença ser mera simulação, de sua realidade ser fictícia, de sua estratégia ser a da contínua fuga e do engano àqueles que imaginam localizá-lo. 


\section{Referências biliográficas}

ARMENGAUD, Françoise [1996], «Foucault», In: Dictionnaire des Philosophes. Paris, Albin Michel, 1996.

BAUDRILLARD, Jean [1984]. Esquecer Foucault. Trad. Cláudio Mesquita e Herbert Daniel, Rio de Janeiro, Rocco, 1984.

BILLOUET, Pierre [2003]. Foucault. Trad. Beatriz Sidou. São Paulo, estação Liberdade, 2003.

BLANCHOT, Maurice [1986]. Michel Foucault tel que je m'imagine. Fata Morgana, s/l, 1986.

CLEMENT, Elisabeth et alii [1994]. La Pihosophie de A à Z, Paris, Haiter, 1994.

Foucault, Michel. [1966a]. As palavras e as coisas. Uma arqueologia das ciências humanas. Lisboa, Portugália Editora, $s / d$.

FOUCAULT, Michel. [1966b]. "La pensée du dehors", Critique, no. 229, junho de 1966, In : Foucault, 1994.

FOUCAULT, Michel. [1967]. "Nietzsche, Freud, Marx». In : Cahiers de Royaumont, tomo VI, Paris, Minuit, 1967. In : Foucault, 1994.

FOUCAULT, Michel, [1968]. "Foucault répond à Sartre ». In : La Quinzaine Littéraire, no. 46, 1968. In : Foucault, 1994.

FOUCAULT, Michel [1969a]. L'Archéologie du savoir. Paris, ..., 1969. [1969b]. La arqueologia del saber. México, Siglo Veintiuno, 1972.]

FOUCAULT, Michel [1969c]. "Linguistique et sciences sociales". Revue tunisienne de sciences sociales, Ano 6, no. 19, dezembro de 1969. In : Foucault, 1994.

FOUCAULT, Michel. [1970]. L'Ordre du discours. Paris, Gallimard, 1971.

FOUCAULT, Michel. et alii [1971a]. O homem e o discurso (A arqueologia de Michel Foucault). Rio de Janeiro, Tempo Brasileiro, 1971.

FOUCAULT, Michel. et alii [1991b]. Estruturalismo e Teoria da Linguagem. Petrópolis, Vozes, 1971.

FOUCAULT, Michel [1994]. Dits et écrits 1954-1969. Paris Gallimard, 1994.

GOUVEA, Margarida de Andrade Serra [1989]. "Michel Foucault e a teoria dos incorporais". Cadernos ICHF (UFF), 8, agosto de 1989.

ROUANET, S. P. [1971] “A gramática do homicídio”. In: Foucault et alii, 1971. 


\footnotetext{
${ }^{1}$ Professor titular da Escola de Comunicações e Artes da USP.

${ }^{2}$ Item 1

O autor Michel Foucault: "ele pode bem revolucionar a imagem tradicional que se faz do autor; é a partir de uma nova posição do autor que ele irá talhar, em tudo aquilo que ele poderia ter dito, em tudo aquilo que ele diz todos os dias, a todo instante, o perfil ainda tremulante de sua obra". (Foucault, 1970: 31).
}

$O$ desmoronamento de Sartre. Pertenço a uma geração de pessoas para quem o horizonte da reflexão estava definido por Husserl de uma forma geral, mais precisamente por Sartre, mais precisamente ainda por Merleau-Ponty. E é evidente que em torno dos anos cinqüenta, cinqüenta e cinco, por razões que são difíceis de desemaranhar e que são igualmente de ordem política, ideológica e científica, é evidente que este horizonte desmoronou para nós. Ele se dissolveu bruscamente e nós nos encontramos diante de um tipo de grande espaço vazio, no interior do qual os procedimentos tornaram-se muito menos ambiciosos, muito mais limitados, muito mais regionais. (Foucault, 1968: 667).

A descontinuidade anônima do saber. Foucault opera num "campo de historicidade em que aparecem as ciências, livre de qualquer atividade constituinte, liberado de qualquer referência a uma origem ou a uma teleologia histórico-transcendental, destacado de qualquer apoio em uma subjetividade fundadora". (Armengaud, 1994: 573).

Signos: antes ternários (estóicos), depois binários. "Desde o estoicismo, o sistema de signos no mundo ocidental fora ternário, pois nele se reconhecia o significante, o significado e a 'conjuntura'. A partir do século XVII, em contrapartida, a disposição dos signos tornar-se-á binária, pois que será definida, com Port-Royal, pela ligação de um significante a um significado (Foucault, 1966a, p. 66). (...) É esse sistema unitário e triplo que desaparece ao mesmo tempo que o 'pensamento por semelhança' e é substituído por uma organização estritamente binária”. (Foucault, 1966a: 93).

Signos e a metafísica. "Esta [a divinatio] supunha sempre sinais que lhe eram anteriores; de modo que o conhecimento que se alojava por inteiro na vaga de um sinal descoberto, afirmado ou secretamente transmitido. A sua tarefa consistia em fazer o levantamento de uma linguagem prévia distribuída pelo mundo por Deus” (Foucault, 1966a, p. 87). “(...) Na gramática geral, sob a forma mais pura, todas as palavras de uma língua eram portadoras de uma significação mais ou menos oculta, mais ou menos derivada, mas cuja primitiva razão de ser residia numa designação inicial. (Foucault, 1966a: 307)”.

$O$ aparecimento do homem. "As ciências do homem desenvolvem-se porque o próprio homem aparece nessa época. Aquilo que se chama 'homem' (um sujeito do conhecimento que é, ao mesmo tempo, um ser natural, um objeto do saber) é uma criação recente e ameaçada de um desaparecimento próximo. Anunciando 'a morte do homem', Foucault não prevê, contudo, a extinção da espécie mas o desaparecimento de uma certa figura do saber". (Clément et alii, 1984, p. 135). Homem: invenção recente. "Antes do fim do século XVIII, o homem não existia" (Foucault, 2006, p. 402). Ver também: "O homem começou a ser pensado como objeto para o saber no momento em que o espaço plano do período clássico, regido pela categoria da representação, passou a ser erodido pela historicidade, categoria central da episteme moderna: o homem surgiu na brecha epistemológica que se formou com o fim da apresentação e o advento da história. Em outras palavras: o homem é um acidente na trajetória do Discurso, e poderá desaparecer quando se modificar a disposição epistemológica que o engendrou". (Apresentação, in: Foucault et alii, 1971: 11)

Ser do homem diferente do ser da linguagem. "A única coisa que sabemos por ora com toda certeza é que nunca na cultura ocidental o ser do homem e o ser da linguagem puderam coexistir e articular-se um com o outro. A sua incompatibilidade foi um dos traços fundamentais do nosso pensamento". (Foucault, 1966a, p. 441). Quem brilha é o ser da linguagem "...toda episteme moderna (...) estava ligada ao desaparecimento do Discurso e do seu reino monótono, à passagem da língua para o campo da objetividade e à sua reaparição simples. Se esta mesma linguagem surge agora com insistência cada vez maior numa unidade que devemos mas que não podemos ainda pensar, não será isso o sinal de que toda esta configuração se vai agora desvanecer e que o homem está em vias de perecer à medida que brilha cada vez mais intensamente no nosso horizonte o ser da linguagem? Tendo sido o homem constituído quando a linguagem estava voltada à dispersão, não irá ele agora dispersar-se quando a linguagem se condensa?" (Foucault, 1966a: 500). 
Quem desaparece é o sujeito da liberdade. "O homem não desaparece na filosofia como objeto do saber mas como sujeito da liberdade e da existência". (Foucault, 1968, p. 664). Discurso: reino do anonimato. "Na análise proposta, as regras de formação se enraízam não na mentalidade ou consciência dos indivíduos, mas no próprio discurso; impõe-se, portanto, segundo uma espécie de anonimato uniforme, a todos os indivíduos que se propõem a falar nesse campo discursivo..." (Foucault, 1969a: 83-84).

Procurou-se o homem e encontraram-se estruturas. "Desde o início do século 19, interrogaram-se as línguas humanas para tentar encontrar algumas das grandes constantes do espírito humano. Esperava-se que, estudando-se a vida das palavras, a evolução das gramáticas, comparando-se as línguas umas com as outras, seria, de qualquer forma, o homem, ele mesmo, que se revelaria, seja na unidade de seu rosto, seja em seus diferentes perfis. Ora, por se ter escavado a linguagem, o que se encontrou? Encontrou-se estruturas". (Foucault, 1968: 664)

${ }^{3}$ Item 2

Fim de um período. "A Arqueologia do saber, como A ordem do discurso, marcam o período - o fim do período - em que Foucault, autor como ele era, pretende pôr a descoberto as práticas discursivas quase puras, no sentido de que eles não remetem senão a si mesmas, às regras de sua formação, a seu ponto de fixação, mesmo que sem origem, à sua emergência, mesmo que sem autor, aos deciframentos que não revelariam nada de escondido". (Blanchot, 1986, p. 19). Jamais fui estruturalista. "Mas, se dirá, Foucault, nesta aventura em que a lingüística representa seu papel, não faz nada, com as intenções que lhe são próprias, além de perseguir as esperanças de um estruturalismo quase defunto. Seria preciso pesquisar (estou pouco confortável para uma tal pesquisa, porque percebo que até o momento não pronunciei, nem para aprovar, nem para desaprovar, o nome desta disciplina efêmera, malgrado a amizade que eu tinha por alguns de seus portadores) por que Foucault, sempre superior às suas paixões, põe-se verdadeiramente em cólera quando se pretende embarcá-lo neste bote, que ilustres capitães já dirigem. As razões são múltiplas. A mais simples (se se puder dizer) é que ele pressente ainda no estruturalismo um ranço de transcendentalismo, pois, o que acontece, então, com estas leis formais que regiriam toda ciência, permanecendo completamente estranhas às vicissitudes da história da qual, entretanto, dependem sua aparição e sua desaparição?" (Blanchot, 1986: 20-21).

Sobre a linguagem: algo além da linguagem. "A linguagem... sempre fez nascer dois tipos de suspeita: de início, a suspeita de que a linguagem não diz exatamente aquilo que ela diz. O sentido que se apreende e que é imediatamente manifestado só pode ser, em realidade, um sentido menor, que protege, restringe e, apesar de tudo, transmite um outro sentido, sendo este, por sua vez, o sentido mais forte e o sentido "por baixo'. É o que os gregos chamam de alegoria e hiponoia. De outra parte, a linguagem faz surgir outra suspeita: que ela transborda, de qualquer maneira, sua forma propriamente verbal e que há outras coisas no mundo que falam e que não são linguagem". (Foucault, 1967, p. 565). Uma linguagem "em outro lugar". "Eu creio que cada cultura, quero dizer, cada forma cultural na civilização ocidental, teve seu sistema de interpretação, suas técnicas, seus métodos, suas maneiras próprias de suspeitar da linguagem, que quer dizer outra coisa do que aquilo que ela diz, e de suspeitar que há uma linguagem em outro lugar que não na linguagem". (Foucault, 1967: 565)

Signos malignos: sintomas em Freud, as palavras em Nietzsche (máscaras). "A idéia de que a interpretação precede o signo implica que o signo não seja um ser simples e benigno, como era o caso ainda no século 16, em que a pletora de signos, o fato de que as coisas se pareciam provava simplesmente a benignidade de Deus e não separavam, a não ser por um véu transparente, o signo do significado. Ao contrário, a partir do século 19, a partir de Freud, Marx e Nietzsche, parece-me que o signo tornou-se maligno; quero dizer que há no signo uma forma ambígua e um pouco equívoca de mal-querença, de 'mal-querer'. E isto na medida em que o signo já é uma interpretação que se não se dá por isso. Os signos são interpretações que tentam se justificar e não o inverso". (Foucault, 1967: 572).

Marx, Nietzsche, Freud. "Marx, Nietzsche e Freud não multiplicaram os signos no mundo ocidental. Eles deram um novo sentido às coisas que não tinham sentido. Em realidade, eles mudaram a natureza do signo e modificaram a forma pela qual o signo em geral poderia ser interpretado". Foucault, 1967, p. 5678. Na ruptura da interpretação, a loucura. "Se se decifra na correspondência de Freud suas perpétuas preocupações desde o momento em que descobriu a psicanálise, pode-se perguntar se a experiência de Freud não é, no fundo, muito semelhante à de Nietzsche. O que está em jogo no ponto de ruptura da interpretação, nesta convergência da interpretação na direção de um ponto que a torna impossível, isso poderia bem ser algo como a experiência da loucura". (Foucault, 1970: 570-1). 
Sobre a "forma exterior". Consultar Foucault, 1966b, p. 521. Escavando as alturas. "Mas, em realidade, não se pode percorrer esta linha descendente quando se interpreta, a não ser para restituir a exterioridade cintilante que foi recoberta e enterrada. É que, se o intérprete deve ir, ele mesmo, até o fundo, como um escavador, o movimento de interpretação é, ao contrário, aquele da coisa que sai do prumo, desse algo cada vez mais alto, que deixa sempre acima dele mostrar-se, de forma cada vez mais visível, a profundidade; e a profundidade é agora restituída como segredo absolutamente superficial, de tal sorte que o vôo da águia, a ascensão da montanha, toda esta verticalidade tão importante em Zaratustra, é, no sentido estrito, o inverso da profundidade, a descoberta que a profundidade não era mais que um jogo e uma dobra da superfície". (Foucault, 1967: 568)

Lingüística, um saber técnico, após Saussure: "A língua e seu funcionamento supõem: pólos emissores de um lado e receptores, de outro; mensagens, isto é, séries de acontecimentos distintos; códigos ou regras de construção destas mensagens que permitem individualizá-las". (Foucault, 1969c, p. 825). E também: "A teoria da língua encontra-se assim ligada à análise de todos os fenômenos da informação. Isto é importante, inicialmente, por causa da possibilidade de formalizar e matematizar altamente as análises lingüísticas...” (Foucault, 1969c, p. 825). “(...) De um golpe, a lingüística encontra-se entrando em conivência com as análises que se referem aos códigos e às mensagens trocadas entre moléculas que constituem nós de células vivas". (Foucault, 1969c, p. 826). Miséria das ciências sociais. "A lingüística encontra-se ligada às ciências sociais de um modo novo, na medida em que agora o social pode ser definido ou descrito como um conjunto de códigos e de informações que caracterizam um grupo dado de emissores e receptores". (Foucault, 1969c: 826).

Ordem do discurso. "Introduzir o acaso, o descontínuo e a materialidade na raiz do pensamento; fazer um inventário dos procedimentos que em toda sociedade controlam a produção do discurso 'administrando o acontecimento aleatório' e 'escapando à pesada, temível materialidade'." (Armengaud, 1994, p. 575). $O$ projeto. "E se se quiser - eu não digo apagar este medo [... sob esta aparente veneração do discurso, sob esta aparente logofilia esconde-se um tipo de medo] - mas analisá-lo em suas condições, em seu jogo, em seus efeitos, é preciso, creio eu, decidir-se a três decisões às quais nosso pensamento hoje resiste um pouco e que correspondem aos três grupos de função que acabo de evocar: questionar nossa vontade de verdade, restituir ao discurso seu caráter de acontecimento, retirar a soberania do significante". (Foucault, 1970: 53).

${ }^{4}$ Item 3

Enunciação e reverberação social, política, etc. "Se se isola, em relação à língua e ao pensamento, a instância do acontecimento enunciativo, não é para tratá-la em si mesma como se ela fosse independente, solitária e soberana. É, ao contrário, para compreender como esses enunciados, enquanto acontecimentos e em sua especificidade tão estranha, podem articular com acontecimentos que não são de natureza discursiva, mas que podem ser de ordem técnica, prática, econômica, social, política, etc." (Foucault et alii, 1971b, p. 24). O acontecimento comunicacional. "Nos parece que nos trabalhos de Foucault a primeira coisa que ressalta é o fato de não estarmos trabalhando com Idéias (nem mesmo a de estrutura), e sim com os acontecimentos". (Gouvêa, 1989: 22).

Enunciados e a sociedade. "O que se trataria de fazer aparecer é o conjunto das condições que regem, em um momento dado e em uma sociedade determinada, a aparição dos enunciados, sua conservação, os laços que são estabelecidos entre eles, a maneira pela qual os grupamos em conjuntos estatutários, o papel que exercem, o jogo dos valores ou das sacralizações que os afetam, a maneira pela qual são investidos em práticas ou condutas, os princípios segundo os quais circulam, são recalcados, esquecidos, destruídos ou reativados". (Foucault et alii, 1971b: 25).

Comunicação: corpos que se misturam. "Para os estóicos, os seres reais podem entrar em relação uns com os outros e por meio desta relação se modificar. Eles não são causas uns dos outros, mas causas uns pelos outros, de certas coisas. Estas modificações não são realidades substanciais, ou qualidades, pois um corpo não pode dar a outro corpo propriedades novas. Logo, o que existe é uma mistura. Mistura dos corpos que se penetram em sua intimidade e tomam uma extensão comum. Assim, quando o fogo esquenta o ferro até o vermelho, por exemplo, é preciso não dizer que o fogo deu ao ferro uma nova qualidade, mas que o fogo penetrou no ferro para coexistir com ele em todas as suas partes". (Gouvêa, 1989: 25) 
As marcas. "Os acontecimentos produzem efeitos. Um dos efeitos é o da marca. Marca é o que fica do encontro entre os corpos, como por exemplo um corte de faca em nosso braço. Só temos o nosso braço; a marca, o corte, é um incorporal, corte não é a faca nem é o nosso braço". (Gouvêa, 1989: 26).

Corpo e acontecimento. "Em Foucault, o corpo também é o lugar de origem. Sobre o corpo se encontra o estigma dos acontecimentos passados do mesmo modo que dele nascem os desejos, os desfalecimentos e os erros. Nele, também, os acontecimentos se atam e se exprimem, mas nele também se desatam, entram em luta, se apagam uns aos outros e continuam seu insuperável conflito. O corpo: superfície de inscrição dos acontecimentos (enquanto que a linguagem os marca e as idéias os dissolvem), lugar da dissociação do EU (que supõe a quimera da unidade substancial), volume em perpétua pulverização. (A genealogia, como análise da proveniência, está no ponto da articulação do corpo com a história)". (Gouvêa, 1989: 8).

Lógica do acontecimento. "Nos parece que Foucault não está particularmente interessado em encontrar na causa da punição dos nossos dias em nossos sistemas sociais, a manifestação ou o efeito de um desejo de vingança ou a do efeito de ódio bem canalizado e, a partir daí, fazer inferências sobre a natureza humana. Parece-nos ocupado em localizar, a partir de múltiplas causas, tanto a emergência de tipos de controle e manutenção de práticas sociais como, também, a emergência de certos tipos de efeitos produzidos por tais controles, efeitos estes que tantos discursos correm para lhe dar satisfação". (Gouvêa, 1989, p. 24. $O$ estruturalismo nega o acontecimento. "Os estruturalistas reagem quando lhes dizem que se esforçam por eliminar o acontecimento, pois na sua visão de parte-todo, questão que o fez emergir, admitem que o todo é mais do que a soma de suas partes. Cabe ao acontecimento ser a parte, o singular, o diferente, porém este é tratado como significante, e é somente na sua relação com o todo que aparece a sua significação. Porém, é justamente aí que reside a negação do acontecimento, pois o esforço dos estóicos reside principalmente em definir os seres de maneira que a qualidade nasça do estado, do modo do próprio acontecimento, sem a intervenção de uma forma exterior (no caso a de todo, a de estrutura). Se a causa ativa se encontra nos corpos, é impossível pensar uma relação implícita de parte-todo, mesmo que este seja pensado como uma virtualidade". (Gouvêa, 1989: 27).

Cada fato, um único acontecimento. "Segundo os estóicos, os fatos são únicos, logo o único objeto da experiência; vê-se, então, que o pensamento que busca observá-los e descobrir suas ligações fica de fora, torna-se estranho a eles". (Gouvêa, 1989: 28).

A história hoje: busca de séries entrecruzadas. "Certamente, a história já de há muito não busca mais compreender os acontecimentos pelo jogo de causas e efeitos na unidade sem forma de um grande devir, vagamente homogêneo ou duramente hierarquizado; mas isto não é para encontrar as estruturas anteriores, estrangeiras, hostis ao acontecimento. É para estabelecer as séries diversas, entrecruzadas, divergentes freqüentemente mas não autônomas, que permitem circunscrever o 'lugar' do acontecimento, as margens de seu acaso, as condições de seu aparecimento". (Foucault, 1970: 58).

O acaso, o descontínuo, a materialidade. "É preciso aceitar a introdução do acaso como categoria na produção de acontecimentos. Aqui ainda se sente a ausência de uma teoria que permita pensar as relações do acaso e do pensamento". (Foucault, 1970, p. 61). “(...) o fino deslocamento que se propõe operar na história das idéias e que consiste em tratar não as representações que podem existir atrás dos discursos mas os discursos como séries regulares e distintas de acontecimentos, este fino deslocamento, temo bem estar reconhecendo aí algo como uma pequena (e, talvez, odiosa) máquina que permite introduzir na raiz mesma do pensamento o acaso, o descontínuo e a materialidade." (Foucault, 1970: 61)

Estoicismo em Foucault: acontecimento não é corpo. "Acontecimento não é nem substância nem acidente, nem qualidade nem processo; o acontecimento não é da ordem dos corpos. E, contudo, ele não é imaterial; é sempre no plano da materialidade que ele encontra efeito, que ele é efeito; ele tem seu lugar e consiste na relação, na coexistência, na dispersão, no recorte, na acumulação, na seleção de elementos materiais; ele não é ato nem propriedade dos corpos; ele se produz como efeito da e na dispersão material". (Foucault, 1970: 59).

Equívocos do método: teologia negativa. "Acaba que Foucault, tentando livrar-se da interpretação ('o sentido escondido'), da originalidade (a atualização de um começo único, a Ursprung heideggeriana) e, enfim, daquilo que ele mesmo chama da 'soberania do significante' (o imperialismo do fonema, do som, do tom, mesmo do ritmo), trabalha, entretanto, ainda sobre o discurso para isolar aí uma forma, à qual ele dará o nome sem prestígio de enunciado: termo do qual é preciso dizer que será mais fácil para ele 
designar aquilo que ele exclui do que aquilo que ele afirma (enunciado), em sua tautologia quase heróica. Leia e releia A arqueologia do saber (título perigoso para ele mesmo, pois evoca aquilo do qual é preciso desviar-se, o logos da arché ou a palavra de origem) e vocês ficarão surpresos de encontrar aí fórmulas da teologia negativa..." (Blanchot, 1986, p. 25-26). Um freudo-marxista? "Depois de se proclamar estruturalista em 1966, Foucault logo renega essa posição e se volta para um freudo-marxismo, que insiste na revolta dos corpos indóceis submetidos à malevolência nas estruturas da sociedade carcerária (1975)”. (Billouet, 2003: 217). “(...) Em 1966, o estilo singular diz que só existem estruturas. Em 1984, o estilo acadêmico diz que só existem singularidades. (Billouet, 2003: 219)"

Fenomenólogo ou analista estrutural? De 1961 a 1963, Foucault tem experiência intensa da loucura e da morte (Artaud, Hölderlin, Sade, Nerval), vizinha de uma análise estrutural da psiquiatria e da medicina moderna. “(...) Esta conjunção entre o tema fenomenológico e uma análise estrutural se dá na equivocidade da decisão, que Michel Foucault apresenta ora como singularidade livre contra as estruturas, ora como deslocamento ínfimo no seio das estruturas". (Billouet, 2003: 216)

A sobrevivência do sujeito. "Tem-se por certo que Foucault, seguindo aqui uma certa concepção da produção literária, se desembaraça pura e simplesmente da noção de sujeito: não mais obras, não mais autor, não mais unidade criadora. Mas as coisas não são tão simples. O sujeito não desaparece: é sua unidade, demasiado determinada, que é a questão, já que o que suscita o interesse e a pesquisa é seu desaparecimento (isto é, esta nova maneira de ser que é o desaparecimento), ou ainda, sua dispersão que não o anula mas que só nos oferece dele uma pluralidade de posições e uma descontinuidade de funções (reencontra-se aqui o sistema de descontinuidades que, certo ou errado, pareceu durante algum tempo próprio à música serial)". (Blanchot, 1986: 29).

Entre 1961 e 1976 a produção histórica das posições correlativas do psiquiatra e do louco, do médico e do doente, do professor e do aluno, etc., dependiam da episteme, dos poderes, dos dispositivos - já que a consciência não guia o mundo. Em compensação, nos dois livros de 1984, as práticas passarão a ser referidas a uma consciência ética mais do que a jogos de poder. (Billouet, 2003, p. 220). Ver também: "E em 1961 começa uma pesquisa arqueológica, ao passo que em 1984 Foucault explicará que a arqueologia da psicanálise (1976) era um desvio - o estilo tão singular de Foucault desaparece ao mesmo tempo em que desaparece o método arqueológico". (Billouet, 2003: 219)

Foucault não vê que a liberação também reprime. "[Foucault diz:] ...nada funciona pela repressão, tudo funciona pela produção - nada funciona pelo recalcamento, tudo funciona pela liberação. Mas é a mesma coisa. Toda forma de liberação é fomentada pelo recalcamento: a das forças produtivas como a do desejo, a dos corpos como a das mulheres, etc. Não há exceção à lógica da liberação: toda força, toda fala liberada é um volteio na espiral do poder. Desta forma a 'liberação sexual' consegue o prodígio de reunir no mesmo ideal revolucionário os dois maiores efeitos do recalcamento: liberação e sexualidade". (Baudrillard, 1984, pp. 40-41). Na psicanálise não há liberação; ela faz nascer o sexual, a fala sexual onde só havia formas incontroladas, instáveis, insensatas, "onde não havia tampouco recalcamento, este leitmotiv que fazemos pesar sobre todas as sociedades anteriores, bem mais que sobre a nossa (...). Elas [as outras culturas antigas] não conhecem o recalcamento nem o inconsciente porque não conhecem o sexual" (idem: 42-43).

Seduzido pelo pensamento técnico. "Se olharmos bem, o poder em Foucault assemelha-se estranhamente a 'esta concepção do espaço do social tão nova quanto a dos espaços físicos e matemáticos atuais', como diz Deleuze subitamente cegado pelas façanhas da ciência. É justamente este conluio que é preciso denunciar, ou do qual se deve rir”. (Baudrillard, 1984, p. 52). “(...) Em Kafka (Deleuze-Guattari), a Lei transcendente, a do Castelo, se opõe à imanência do desejo na contigüidade dos escritórios. Inevitável não ver que a Lei do Castelo tem seus 'rizomas' nos corredores e nos escritórios - a barra do tribunal, a ruptura da lei simplesmente se multiplica infinitamente na sucessão alveolar e molecular. O desejo é a versão molecular da Lei. Estranha coincidência, por toda parte, dos esquemas do desejo e dos esquemas de controle". (Baudrillard, 1984: 54).

O poder como algo continuamente reversível. "Não existem mais demonstrações de força do poder, simplesmente não há mais nada, nem aquém, nem além (a passagem do 'molar' ao 'molecular' é, ainda, em Deleuze, uma revolução do desejo, em Foucault é uma anamorfose do poder) - porém desse fato escapa a Foucault que o poder está se extinguindo, mesmo o poder infinitesimal, que o poder não está somente pulverizado, que está minado por uma reversão, corroído por uma reversibilidade e uma morte 
que não podem aparecer apenas no processo genealógico”. Baudrillard, 1984, p. 60-61. “(...) Foucault não percebe que o poder não está nunca ali, que sua instituição, como a do espaço perspectivado e 'real' da Renascença, é apenas uma simulação de perspectiva, que ele não tem mais realidade do que a acumulação econômica..." (Baudrillard, 1984, p. 62-63). Poder não é "uma coisa". "Ter ou não ter, pegar ou largar, encarná-lo ou contestá-lo - se o poder fosse isso, nem existiria. (Baudrillard, 1984, p. 65). (...) O próprio poder nem sempre deixa-se levar pelo poder, e o segredo dos grandes políticos foi saber que o poder não existe. (Baudrillard, 1984, p. 90)... Quando falamos tanto do poder, é porque não está em parte alguma (Baudrillard, 1984: 92)”. 